\title{
PEMANFAATAN MULTIMEDIA DALAM MEDIA PEMBELAJARAN INTERAKTIF UNTUK MENINGKATKAN MINAT BELAJAR SISWA
}

\author{
Novia Lestari ${ }^{1)}$, Rini Wirasty $B^{2)}$ \\ Universitas Mahaputra Muhammad Yamin (UMMY) Solok ${ }^{1)}$ \\ Universitas Mahaputra Muhammad Yamin (UMMY) Solok ${ }^{2)}$ \\ Novialestari@ummy.ac.id \\ riniwirasty@gmail.com
}

\begin{abstract}
ABSTRAK
Peran guru di dalam setiap kegiatan pembelajaran di sekolah sangatlah penting. Guru bertanggungjawab atas suksesnya setiap kegiatan pembelajaran yang telah dirancangnya. Guru yang tidak optimal di dalam mempersiapkan desain pembelajaran akan menghasilkan kegiatan pembelajaran yang tidak optimal. Hal itu menyebabkan capaian pembelajaran yang telah ditargetkan tidak tercapai. Dengan demikian, pengembangan kompetensi guru khususnya di bidang keterampilan dalam pembuatan media pembelajaran sangat penting untuk dilakukan. Namun permasalahan yang masih sering dijumpai di beberapa sekolah adalah masih kurangnya kemampuan para guru dalam mengadopsi perkembangan teknologi informasi, terutama komputer. Selain itu guru masih kesulitan dalam menemukan sumber atau media pembelajaran yang tepat dan memiliki keefektifan yang tinggi. Karena media yang selama ini digunakan para guru adalah media pembelajaran yang disajikan secara tekstual, seperti: buku teks dan LKS. Padahal kecanggihan teknologi informasi menawarkan berbagai media pembelajaran yang lebih dinamis dan menarik minat belajar siswa.
\end{abstract}

Kata kunci: Multimedia, Media pembelajaran, Interaktif, Teknologi informasi

\begin{abstract}
The role of the teacher in each learning activity at school is very important. The teacher is responsible for the success of each learning activity he has designed. Teachers who are not optimal in preparing learning designs will produce learning activities that are not optimal. This causes the achievement of learning that has been targeted is not achieved. Thus, the development of teacher competence, especially in the field of skills in making learning media is very important to do. But the problems that are still often encountered in some schools are still the lack of the ability of teachers to adopt developments in information technology, especially computers. In addition, teachers are still having difficulty in finding the right learning resources or media and have high effectiveness. Because the media that has been used by teachers is learning media that are presented textually, such as: textbooks and LKS. Though the sophistication of information technology offers a variety of learning media that are more dynamic and attract students' interest in learning.
\end{abstract}

Keywords: Multimedia, Learning Media, Interactive, Information Technology

\section{PENDAHULUAN}

Undang Undang Sisdiknas Nomor 20 Tahun 2003 menjelaskan bahwa manusia membutuhkan pendidikan dalam kehidupannya, karena pendidikan merupakan usaha agar manusia dapat mengembangkan potensi dirinya melalui proses pembelajaran dan atau cara lain, yang dikenal dan diakui oleh mayarakat (Hidayat dkk., 2018).
Namun proses pembelajaran melalui dunia pendidikan juga harus mampu menawarkan pembelajaran yang berkualitas demi mewujudkan tujuan pendidikan yang dapat meningkatkan kualitas sumber daya manusia bangsa Indonesia. Sehingga pembaharuan di bidang pendidikan sangat dibutuhkan dan menjadi salah satu tolak ukur dalam meningkatkan 
kualitas pendidikan nasional itu sendiri (Fakhruddin, 2017).

Perkembangan teknologi

informasi yang semakin meningkat bisa teraktualisasi dalam semua bidang kehidupan dan tidak dapat dilepaskan dari kebutuhan manusia termasuk dalam bidang pendidikan. Dimana kontribusi teknologi informasi dalam dunia pendidikan di era globalisasi ini dapat dipandang dari berbagai aspek, baik dalam pengelolaan data dan penyajian informasi, maupun proses belajar mengajar. Karena pada dasarnya teknologi informasi dapat memfasilitasi suatu proses dalam mengumpulkan, mengelola, menyimpan, menyelidiki, membuktikan dan menyebarkan informasi yang benar, cepat, akurat dan transparan sehingga dunia pendidikan di Indonesia menjadi kompetitif dan memiliki daya saing yang kuat (Waldopo, 2011).

Saat ini berbagai inovasi pendidikan terus dilakukan seiring perkembangan teknologi, hal ini bertujuan untuk meningkatkan kualitas pendidikan yang masih cenderung rendah. Inovasi pendidikan yang dilakukan diantaranya yaitu pengembangan kurikulum, inovasi pembelajaran, dan pemenuhan sarana prasarana pendidikan (Septianita, 2014).

Untuk menumbuhkan minat belajar siswa, maka guru dituntut untuk mampu membuat pembelajaran lebih menarik dan inovatif, sehingga mendorong siswa dapat belajar secara optimal baik dalam belajar individual maupun dalam proses pembelajaran di dalam kelas (Rusman, 2011).. Usaha untuk mencapai pembelajaran yang menarik dan inovatif yaitu salah satunya dengan menggunakan media pembelajaran yang bisa digunakan oleh guru dalam proses belajar mengajar, salah satunya dengan media pembelajaran berbasis multimedia (Waskito, 2014).

Namun permasalahan yang masih sering dijumpai di beberapa sekolah adalah masih kurangnya kemampuan para guru dalam mengadopsi perkembangan teknologi informasi, terutama komputer, selain itu guru masih kesulitan dalam menemukan sumber atau media pembelajaran yang tepat dan memiliki keefektifan yang tinggi. Karena media yang selama ini digunakan para guru adalah media pembelajaran yang disajikan secara tekstual, seperti: buku, teks dan LKS

Hal ini juga terjadi di SMP N 1 Bukit Sundi yang merupakan mitra pada Program Kemitraan Masyarakat ini.

\section{METODE PELAKSANAAN}

Metode pelaksanaan program kemitraan masyarakat berdasarkan permasalahan yang dihadapi mitra adalah sebagai berikut:

1. Diskusi awal dengan mitra untuk mengetahui kondisi dan kebutuhan mitra dalam pemanfaataan teknologi informasi. Pada tahap ini, tim pengusul dan mitra menetapkan tujuan bersama untuk menyelesaikan permasalahan yang ada, sehingga guru-guru SMPN 1 Bukit Sundi fasih dalam mengoperasikan teknologi informasi khususnya komputer/ laptop yang mampu menunjang dalam proses belajar mengajar. 
2. Pelatihan

a. Mitra diberikan pelatihan tentang pemanfaatan teknologi informasi berupa penggunaan komputer atau laptop, karena sebelumnya mitra belum maksimal dalam penggunaan teknologi informasi. Pada pelatihan ini, guru-guru dilatih untuk mampu menggunakan aplikasi sederhana yaitu power point dan preezy untuk membuat media pembelajaran yang bisa menarik minat belajar siswa.

b. Mitra diberikan pelatihan tentang pembuatan media pembelajaran interaktif berbasis multimedia. Pada tahap awal, guru-guru akan dikenalkan pada aplikasi Macromedia flash yang berbasis multimedia. Dimana aplikasi ini dapat digunakan untuk membuat media pembelajaran yang nantinya berisi materi-materi pelajaran, latihan soal, bahkan pembahasan yang semua itu dibuat dengan tampilan yang interaktif, sehingga siswa nantinya lebih tertarik memperhatikan materi pelajaran dan semangat dalam mengerjakan latihan soal serta pembahasannya.

3. Evaluasi dan Pendampingan

Kegiatan evaluasi dilakukan secara langsung oleh pengusul. Evaluasi berupa hasil kerja peserta (guru mitra) terhadap pemanfaatan teknologi informasi dalam pembelajaran. Proses evaluasi dilaksanakan untuk mengetahui kekurangan dan kendala dalam pelaksanaan kegiatan. Setelah dilakukan pelatihan kepada mitra, diharapkan ada peningkatan kualitas dan wawasan mitra tentang pemanfaatan teknologi informasi dalam kegiatan pembelajaran. Setelah pelatihan dan pembinaan dilakukan, masing-masing peserta pelatihan nantinya harus mampu membuat media pembelajaran interaktif yang sesuai dengan materi pelajaran yang diajarkan.

\section{HASIL DAN PEMBAHASAN}

Dari tinjauan ke lapangan didapat permasalahan-permasalahan yang dihadapi guru-guru SMP N 1 Bukit Sundi adalah Guru-guru yang mengajar kebanyakan guru-guru berusia di atas 40 tahun ke atas yang belum maksimal terhadap penggunaan teknologi informasi, sehingga guru-guru agak kesulitan dalam mendalami pemanfaatan dan perkembangan teknologi informasi. Ini membuat proses belajar mengajar di SMP N 1 Bukit Sundi masih menerapkan sistem konvensional yaitu menggunakan media pembelajaran berupa papan tulis dimana guru-guru mencatatkan materi pelajaran dan kemudian menerangkannya pada siswa/i. Hal ini terjadi rutin dan terus menerus, sehingga membuat siswa hanya terpaku pada guru dan semua yang ada di papan tulis semata, sehingga banyak siswa yang bosan dengan materi pelajaran yang diberikan yang mengakibatkan kurangnya minat belajar siswa. Ini membuat kreatifitas siswa tidak banyak berkembang dan semangat serta minat belajar siswa rendah.

Kegiatan pembelajaran yang masih bersifat konvensional akan berdampak pada kejenuhan siswa dan pemahaman konsep dasar yang 
tidak maksimal. Sentuhan teknologi yang masih sangat kurang membuat guru dan sekolah kurang kreatif dalam merancang kegiatan pembelajaran yang menarik. Kurangnya kemampuan guru dalam merancang proses pembelajaran melalui pemanfaatan teknologi informasi dapat berdampak pada rendahnya minat belajar siswa pada. IPTEK yang didapatkan mitra dalam Program Kemitraan Masyarakat Stimulus ini adalah sebagai berikut :

a. Keterampilan dalam pembuatan media pembelajaran menggunakan aplikasi sederhana namun tetap menarik yaitu power point dan preezy.

b. Keterampilan dalam media pembelajaran interaktif berbasis multimedia menggunakan Macromedia Flash.

Berikut contoh tampilan media pembelajaran interaktif berbasis multimedia menggunakan aplikasi Macromedia Flash :

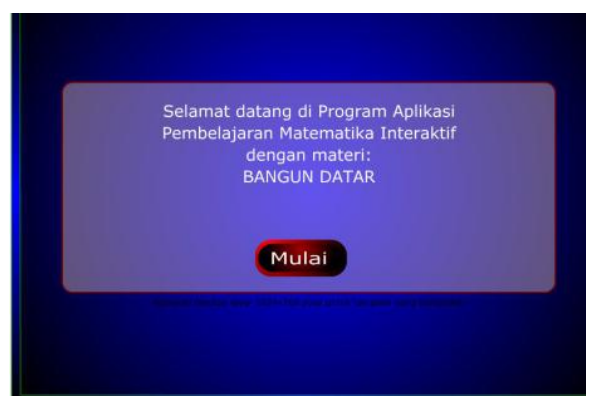

Gambar 1. Tampilan Menu Utama

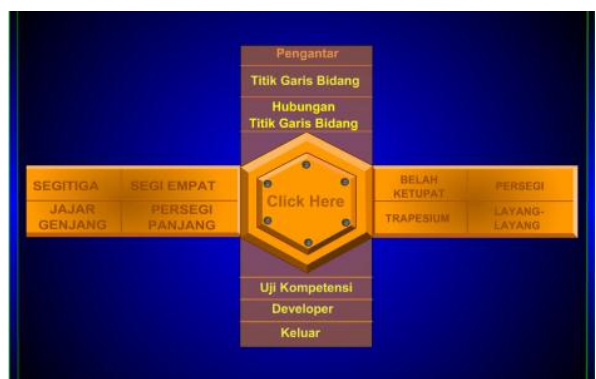

Gambar 2. Pilihan Materi Pelajaran

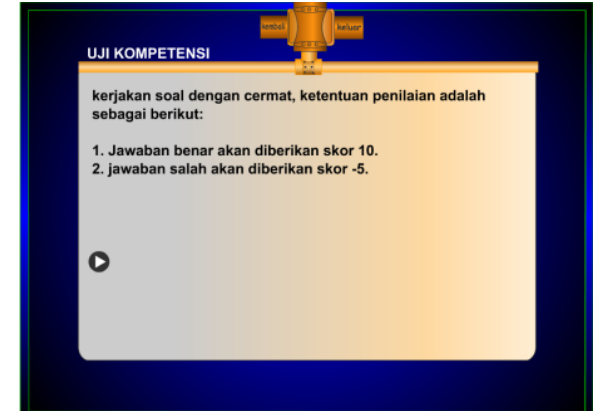

Gambar 3.Petunjuk Uji Kompetensi

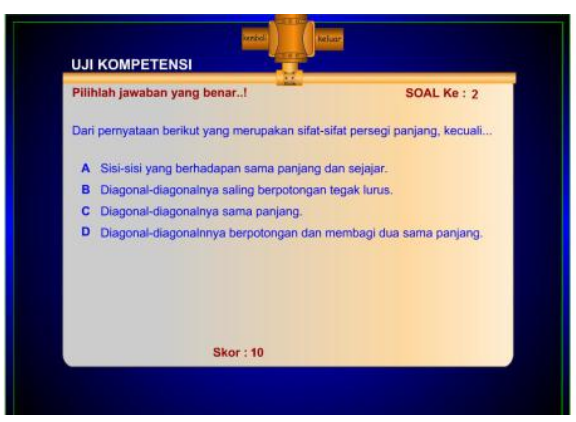

Gambar 4. Soal Uji Kompetensi

Dari gambar di atas, dapat dilihat bahwa media pembelajaran menggunakan Macromedia Flash tidak hanya berisi materi pelajaran saja, tapi bisa juga dilengkapi dengan soal-soal uji kompetensi untuk menilai pemahaman siswa terhadap materi yang telah diberikan. Dengan media pembelajaran interaktif seperti tampilan di atas, siswa lebih semangat lagi dalam mengikuti proses belajar mengajar, sehingga memberi pemahaman lebih dan nilai tambah bagi siswa tersebut.

\section{KESIMPULAN}

Dengan kegiatan PKM yang telah dilakukan, maka didapat adanya nilai tambah bagi guru-guru SMPN 1 Bukit Sundi, dimana dengan kegiatan pelatihan yang telah 
dilakukan, dapat memfasilitasi guruguru SMP N 1 Bukit Sundi dalam hal pelatihan dan pemanfaatan teknologi informasi, terutama yang berhubungan dengan proses belajar mengajar yaitu pembuatan media pelajaran interaktif berbasis multimedia. Dimana dengan digunakannya media pembelajaran interaktif ini, guru-guru lebih kreatif lagi dalam menyajikan materi pembelajaran kepada siswa, sehingga siswa lebih tertarik terhadap pelajaran yang diikuti dan semangat serta minat belajar mereka semakin tinggi agar tercapai output dari proses belajar mengajar yang diinginkan demi mewujudkan citacita pendidikan nasional menciptakan generasi penerus bangsa yang berilmu, cakap, kreatif, mandiri (SOSBUD, 2013).

\section{REFERENSI}

Fakhruddin dkk. (2017). "Ibm Guru Sekolah Dasar Melalui Upaya Peningkatan Kualitas Guru Dengan Pelatihan Pengembangan Media Pembelajaran Pada Implementasi Kurikulum 2013". Jurnal ABDIMAS Vol. 21 No. 2.

Hidayat, Muhammad Fikri dkk. (2018). "Upaya Peningkatan Kompetensi Dalam Membuat ELearning Bagi Guru SMK Dinamika Kota Tegal". Jurnal Abdimas PHB Vol 1 No .
Rusman, Deni Kurniawan, dan Cepi Riyana. Pembelajaran Berbasis teknologi Informasi dan Komunikasi. Jakarta: Rajawali Pers. (2011).

Septianita, $\quad$ Riska. 2014. "Pengembangan Media Pembelajaran Buku Saku Fisika Dengan Teknologi Augmented Reality Berbasis Android pada Materi Fluida Statis untuk Kelas X SMA IPA". Jurnal Online UM. 2 (2014), p. 1-11.

SOSBUD. 2013. "Penguasaan, Pemanfaatan dan Pemajuan Teknologi Informasi dan Komunikasi (TIK) guna Kejayaan bangsa dalam rangka Ketahanan Nasional". Jurnal Kajian LEMHANNAS. 16 (2013), p. $42-55$.

Undang-Undang Republik Indonesia Tentang Pendidikan Nasional Nomor 20 Tahun 2003.

Waskito, Danang. (2014). "Media Pembelajaran Interaktif Matematika Bagi Sekolah Dasar Kelas 6 Berbasis Multimedia". Speed Journal (Sentra Penelitian Engineering dan Edukasi) Volume 11 No 3.

Waldopo. 2011. "Analisis Kebutuhan Terhadap Program Multi Media Interaktif Sebagai Media Pembelajaran". Jurnal Pendidikan dan Kebudayaan. 17 (2011), p. 244-253. 